\title{
An Innovative Program for Success: The National College Advising Corps
}

\author{
Libby V. Morris
}

Published online: 17 February 2009

(C) Springer Science + Business Media, LLC 2009

In December 2008, the University of Georgia (UGA) joined the National College Advising Corps (see NCAC at http://www.advisingcorps.org/) with financial support from a Georgiabased foundation. The Corps is a nationwide consortium of colleges and universities focused on increasing access to higher education and the actual decision to attend. Specifically, the corps aims "to increase the number of low-income, first-generation, and underrepresented students entering and completing higher education."

According to the 2006 report entitled Measuring Up: The National Report Card on Higher Education (http://measuringup.highereducation.org/), since the early 1990s the U.S. has made no real progress in increasing the number of young adults who go on to some form of postsecondary education; and disparities in participation by race and income continue to plague a large number of states. For example, in Virginia, 58\% of high income adults aged 18-24 enroll in college, while only $14 \%$ of low income students do so. The need to increase college participation and completion is heightened by the realities of the global workplace, where companies search not just across states and regions, but around the globe for educated workforces and a competitive edge. The U.S. Department of Education reports that the fast growing job categories of today require postsecondary education, and a high-school diploma alone will leave many with low-paying jobs and no clear career path. Perhaps the current global downturn in the economy and the climbing job losses across the nation could have one silver lining if we improve educational access, support more first-time and returning students for participation in degree programs and certificates, and emerge with a greater commitment to postsecondary opportunities overall.

The enormity of the task to improve college participation rates will require multiple efforts in a variety of formats. NCAC is a targeted effort that has the potential to "move the needle", i.e., make a significant change in the number of students choosing to attend college. The initial objective is to supplement high school counselors' college advising work. The National Center for Education Statistics places the ratio of counselors to high school students at 1:488. Consequently, with too many students to serve, many firstgeneration students never receive assistance with the complex college application process.

L. V. Morris $(\square)$

Institute of Higher Education, University of Georgia, 102 Meigs Hall, Athens, GA 30602-6772, USA e-mail: lvmorris@uga.edu 
It is estimated that one-quarter of low-income students with top quartile scores on standardized tests never go to college. Peer advisers can increase advising services and affect the application rate. Secondly, NCAC engages colleges and universities in increasing college attendance. So, it is not only about recruiting students who would be ready to apply and go to college and competing for those who are planning to go, but committing to the high schools with need, using the peer advisor model to help first-generation, college-able, and other qualified students understand how to get into college-anywhere and everywhere. NCAC is a program that with a little exposure for fund-raising and adequate in-kind support from colleges, which is currently the case at UGA, the advisers can and will make a difference.

The status now is as follows: the 13-partner NCAC institutions, ranging from California to Massachusetts, place recent college graduates from their institution into high schools across their respective states. Currently, the partner institutions vary by program in numbers of advisers; some have fewer than five advisors, and others have over 20. UGA will begin with four advisers at four schools. The limitation on the number of advisers is influenced by program capacity and available funding for salaries.

Advisors are recruited during spring semester and then trained in the summer before placement in the high school in the fall. The training curriculum includes information on financial aid, student-institutional fit, admissions tests and preparation, college choice and curricula, completing applications, mentoring applicants and families, and the list goes on. The adviser's purpose is to extend the reach of the permanent high school counselor(s) with a focus on encouraging college application and attendance, recognizing that college advising is only one of the many jobs of the professional high school counselor. Adviser training culminates in early August in a 3-day session for all advisers nationwide at the University of North Carolina at Chapel Hill, the headquarters for NCAC. Throughout the year, advisers are brought back to the home campus for updates and are visited in the high schools by the program directors and coordinators.

Importantly, NCAC is not just another "do good" program. The consortium is setting benchmarks for growth, refining processes for advising, and establishing a common set of data elements for accountability and improvement. Started in 2004 at the University of Virginia with 14 advisers, today NCAC has 13 partners, 124 active advisers, and serves more than 37,000 high school students. To launch the national program, the Jack Kent Cooke Foundation provided $\$ 10$ million in funding to ten of the partners to replicate the University of Virginia program. We are pleased that a Georgia-based foundation is providing initial funding to the Institute of Higher Education to launch the UGA program. All of which brings us back to Georgia - where the need for improvement in the number of students choosing to go on to college is quite evident. According to the Measuring Up report, in 2006 the top states had $41 \%$ of adults 18-24 enrolled in college, while Georgia was much lower at $30 \%$. Numerous indicators are used to compile the state by state information across five categories: preparation, participation, affordability, completion, and benefits. In college completion Georgia received an A, but in participation a $\mathrm{D}+$. Georgia still has much work to do to improve educational levels overall, but it is encouraging to note that the state has shown improvement in four of five categories since 1992.

At the Institute of Higher Education (http://uga.edu/ihe/), we study the processes and programs of colleges and universities. Thus, I am especially pleased that we are an active participant in this innovative program of college advising and access. I look forward to saying in the future that collectively "we moved the needle" on college enrollment and completion in Georgia and nationwide. This significant program merits your attention. 